\title{
Kegiatan Pembuatan Aplikasi Pengisian dan Laporan Nilai Ujian Menggunakan Microsoft Access
}

\author{
Yudo Devianto ${ }^{1 *}$, Saruni Dwiasnati ${ }^{2}$ \\ 1, 2 Universitas Mercu Buana \\ ${ }^{*}$ Corresponding author \\ E-mail: yudo.devianto@mercubuana.ac.id
}

\section{Article History:}

Received: 20-08-2020

Revised: 06-10-2020

Accepted: 05-05-2021

Keywords:

\begin{abstract}
Analisis situasi sangat dibutuhkan untuk setiap kegiatan. Analisis situasi diperlukan untuk mendapatkan data terkait kondisi fisik, sarana maupun prasarana yang ada di $S D$ Negeri 05 Meruya Utara. Hasil analisis situasi inilah yang kemudian akan dijadikan pedoman dalam menentukan program kerja individu maupun kelompok. Tempat dimana akan dilakukan kegiatan Pengabdian Kepada Masyarakat adalah SD Negeri 05 Meruya Utara. Peserta yang akan terlibat dalam kegiatan ini adalah para guru dan tata usaha sekolah, mereka membutuhkan pembaharuan pengetahuan tentang aplikasi office tersebut. Salah satu aplikasi office yang dibutuhkan adalah Microsoft Access. Tahapan pelaksanaan yaitu melakukan koordinasi dengan Sekolah Dasar Negeri 05 Meruya Utara terkait siapa saja peserta yang akan mengikuti pelatihan, jumlah peserta, dan penjadwalan. Membatasi jumlah peserta 20 orang. Memberikan undangan kepada peserta untuk dapat hadir pada hari yang sudah ditentukan atau disepakati bersama. Keberhasilan pelaksanaan program pengabdian masyarakat ini dapat dilihat, respons positif dari peserta pelatihan, meningkatnya keterampilan peserta setelah mendapat pelatihan.
\end{abstract}

Microsoft Office, Microsoft Access, SD Negeri 05 Meruya Utara, Pengabdian Kepada Masyarakat.

\section{Pendahuluan}

Analisis situasi sangat dibutuhkan untuk setiap kegiatan. Analisis situasi diperlukan untuk mendapatkan data terkait kondisi fisik, sarana maupun prasarana yang ada di SD Negeri 05 Meruya Utara. Hasil analisis situasi inilah yang kemudian akan dijadikan pedoman dalam menentukan program kerja individu maupun kelompok. Teknologi informasi yang terus berkembang, sebagai contoh perkembangan aplikasi office yang dimiliki oleh Microsoft. Oleh karena itu dibutuhkan pembaharuan atas perkembangan tersebut, yaitu pembaharuan atas pengetahuan para individu.

Tempat dimana akan dilakukan kegiatan Pengabdian Kepada Masyarakat, SD Negeri 05 Meruya Utara, yang akan terlibat dalam kegiatan ini adalah para tenaga pendidik, mereka membutuhkan pembaharuan pengetahuan tentang aplikasi office 
tersebut. Gambaran Umum dan Profil Sekolah, sekolah yang didirikan berdasarkan SK Pendirian Sekolah nomor D.III-5502/c/12/75 pada tanggal 01 Oktober 1975 dengan NPSN 20101373. Berdasarkan data rekapitulasi yang diunduh pada tanggal 04 Desember 2018 jam 23:48, saat ini memiliki ruang sebanyak 25 ruang kelas, 1 ruang lab, dan 1 ruang perpustakaan. Saat ini memiliki 712 peserta didik dengan jenis kelamin laki-laki sebanyak 389 siswa dan berjenis kelamin perempuan sebanyak 323 siswi, dipimpin oleh kepala sekolah Dra. H. Lyes Nursiyati. Dengan guru sebanyak 31 orang dengan jenis kelamin laki-laki sebanyak 11 orang dan perempuan sebanyak 20 orang.

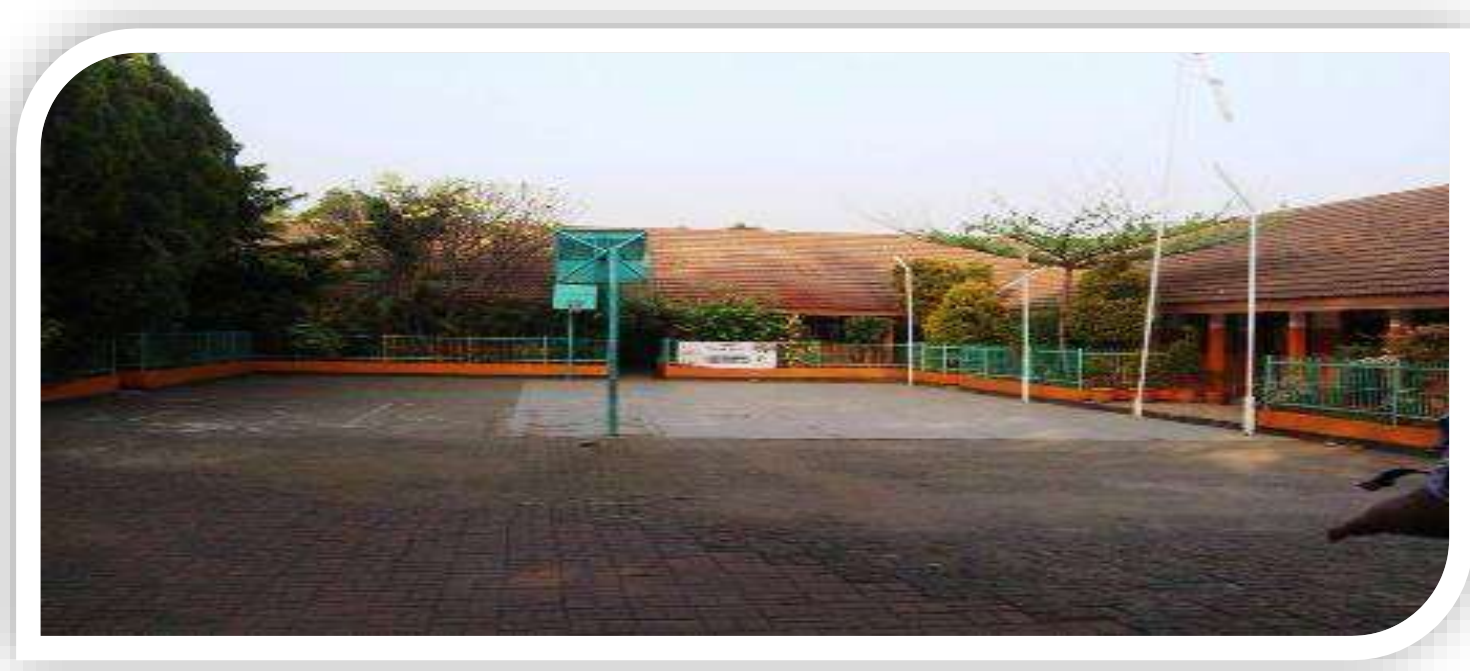

Gambar 1. Lokasi Kegiatan Pengabdian Kepada Masyarakat

Berdasarkan observasi dan diskusi langsung dengan mitra didapatkan beberapa permasalahan yang dihadapi yaitu:

Tabel. 1 Uraian Permasalahan Mitra

\begin{tabular}{ll}
\hline \multicolumn{1}{c}{ Pemasalahan Mitra } & \multicolumn{1}{c}{ Uraian } \\
\hline $\begin{array}{l}\text { Kurang Memahami manfaat lebih dari } \\
\text { aplikasi Microsoft Office. }\end{array}$ & $\begin{array}{l}\text { Para guru dan tata usaha masih kurang } \\
\text { memahami akan manfaat lebih dari } \\
\text { aplikasi Microsoft Office ini, salah } \\
\text { satunya adalah Microsoft Access. }\end{array}$
\end{tabular}

Sumber: diolah, 2020

\section{Metode}

Adapun metode yang digunakan dalam kegiatan pengabdian masyarakat ini antara lain: 
a. Memberikan informasi dan pengetahuan umum tentang apa itu Microsoft Access, serta penggunaan Microsoft Access tersebut.

b. Memberikan pengenalan tentang fitur-fitur yang ada pada Microsoft Access tersebut.

c. Memberikan pelatihan dan tutorial dengan membuat contoh aplikaasi pengisian dan laporan nilai ujian menggunakan Microsoft Access tersebut.

d. Indikator Keberhasilan

1. Para Guru dan Tata Usaha mampu membuat aplikasi pengisian dan pelaporan nilai ujian menggunakan Microsoft Access.

2. Para Guru dan Tata Usaha antusias dengan membuat aplikasi pengisian dan pelaporan nilai ujian menggunakan Microsoft Access.

Diagram metode dari pelaksanaan PKM dapat terlihat pada Gambar 2.

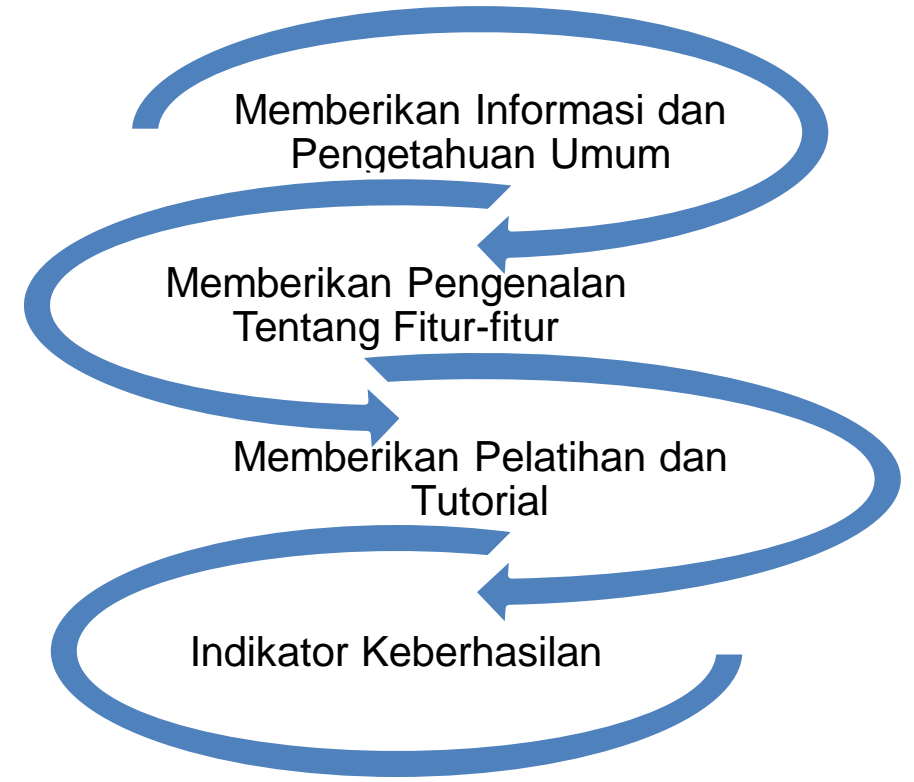

Gambar 2. Metode Pelaksanaan PKM

\section{Hasil}

Kegiatan pelatihan ini berlangsung dalam dua tahap, yaitu tahap koordinasi dan tahap pelaksanaan. Pada tahap koordinasi, tim berkomunikasi dengan kepala sekolah SD Negeri 05 Meruya Utara, untuk membahas masalah yang tengah dihadapi, rencana pelatihan, dan pihak-pihak yang terlibat. Beberapa guru dan tata usaha dipilih untuk mengikuti pelatihan dimaksud.

Setelah menyepakati jadwal, pelatihan tersebut dilaksanakan pada hari Kamis, 24 Januari 2020, di SD Negeri 05 Meruya Utara selama 6 jam mulai dari pukul 09.00 WIB hingga pukul 15.00 WIB. Materi yang dilatihkan yaitu, Pengantar dan penjelasan tentang Microsoft Office dan Pelatihan pembuatan aplikasi entri nilai ujian dengan 
Microsoft Access, kegiatan PKM ini diikuti oleh beberapa kelompok PKM, kelompok saya sendiri melakukan pelatihan pada sesi satu. Adapun jadwal dan materi perlatihan dapat dilihat pada Tabel 2.

Tabel. 2 Jadwal dan Materi Pelatihan

\begin{tabular}{ccl}
\hline Hari/Tanggal & Jam & \multicolumn{1}{c}{ Materi } \\
\hline & $09.00-10.00$ & $\begin{array}{l}\text { Pengantar dan penjelasan tentang } \\
\text { Microsoft Office. }\end{array}$ \\
24 Januari 2020 $10.05-12.00$ & $\begin{array}{l}\text { Pelatihan pembuatan aplikasi entri nilai } \\
\text { ujian dengan Microsoft Access. } \\
\text { Istirahat/Makan Siang } \\
\text { Pelatihan dilanjut oleh Tim PKM lain } \\
\text { dengan pembahasan lain }\end{array}$ \\
& $12.05-12.30$ &
\end{tabular}

Sumber: diolah, 2020

Dalam pelaksanaan pelatihan ini, fasilitas proyektor disediakan oleh pihak sekolah, dan para peserta membawa laptop pribadi masing-masing, sehingga pada saat penyampaian materi dan praktek pelatihan dapat berjalan dengan baik.

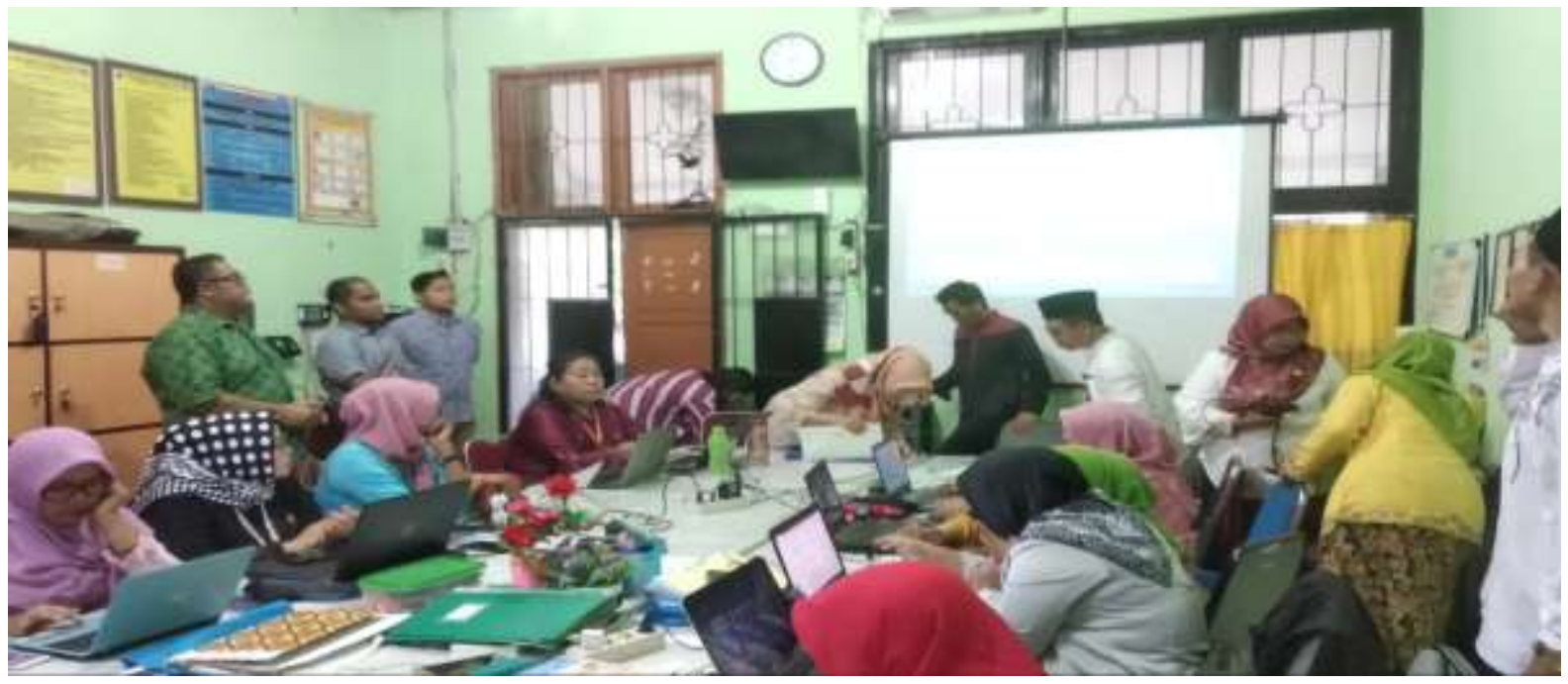

Gambar 3. Kegiatan Pengabdian Kepada Masyarakat

\section{Diskusi}

Antusiasme pihak Sekolah Dasar 05 Meruya Utara, menyambut dengan baik tawaran kerjasama sebagai mitra dalam pengabdian masyarakat ini. Materi pelatihan yang diberikan sangat sesuai dengan level Guru dan Staf Tata Usaha Sekolah Dasar 05 Meruya Utara terlihat dari efektifitas dan tingkat kesulitan pengenalan aplikasi baru yang tidak terlalu memberatkan bagi peserta pelatihan. Situasi dan kondisi pelatihan 
sangatlah kondusif dan memberikan kenyamanan bagi peserta pelatihan.

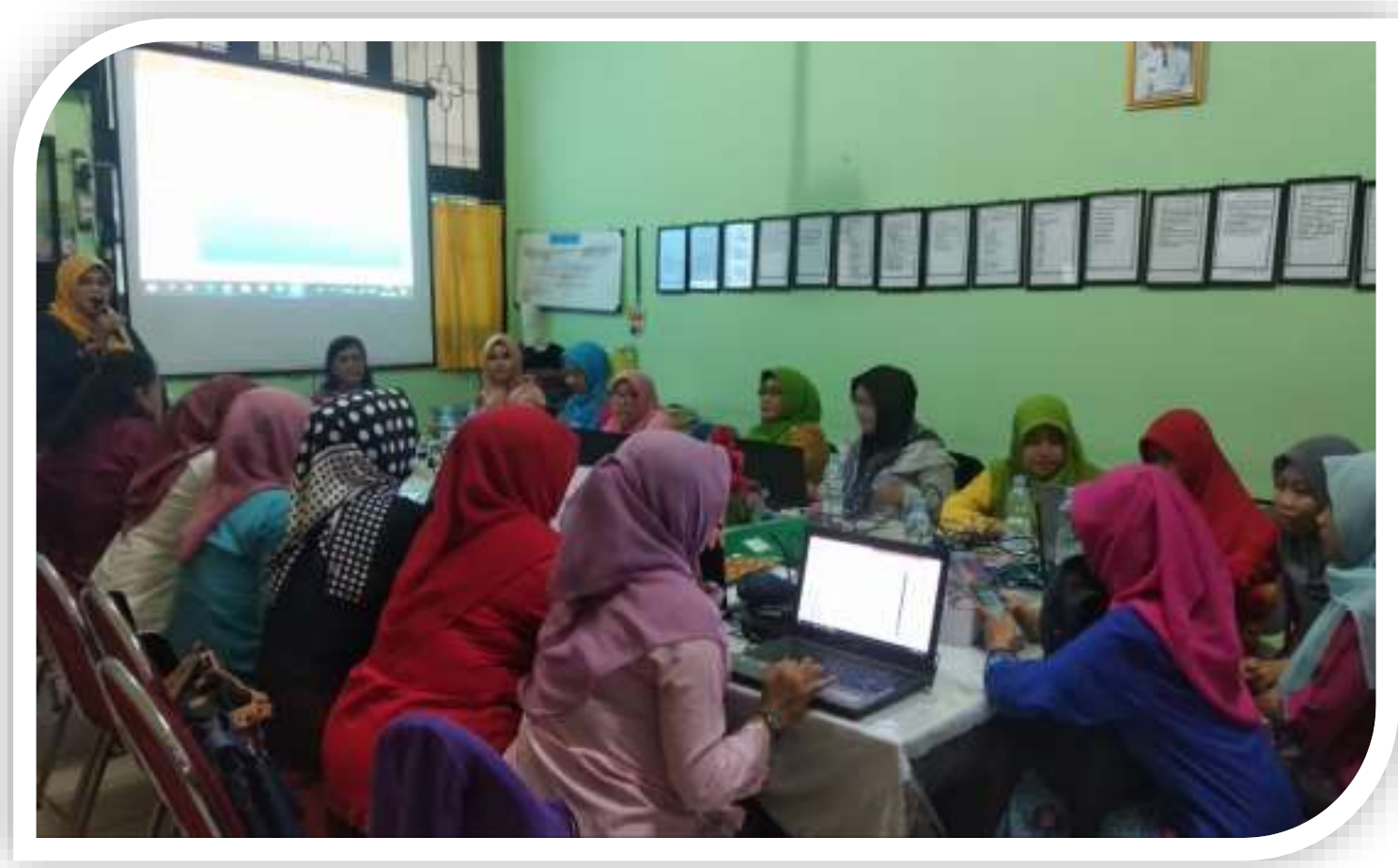

Gambar 4. Suasana Kegiatan Pelatihan

Potensi dan kemampuan pembelajaran dari Guru dan Staf Tata Usaha Sekolah Dasar 05 Meruya Utara peserta pelatihan terlihat baik, terbukti dari hasil observasi yang dilakukan selama pelatihan berlangsung. Guru dan Staf Tata Usaha Sekolah Dasar 05 Meruya Utara mampu mengikuti dan menyelesaikan dengan baik tugastugas yang diberikan oleh para dosen tutor.

Keberhasilan pelaksanaan program pengabdian masyarakat ini dapat dilihat dari dua tolak ukur sebagai berikut:

Tabel. 3 Tolak Ukur Keberhasilan Pelatihan

\begin{tabular}{ll}
\hline \multicolumn{1}{c}{ Tolak Ukur } & \multicolumn{1}{c}{ Keterangan } \\
\hline $\begin{array}{l}\text { Respons positif dari peserta } \\
\text { pelatihan }\end{array}$ & $\begin{array}{l}\text { Respons peserta pelatihan akan diukur melalui } \\
\text { observasi selama pelatihan berlangsung dan } \\
\text { dengan mengadakan diskusi yang menyangkut } \\
\text { kesan, saran, kritik dan ususlan peserta } \\
\text { pelatihan terhadap program pengabdian } \\
\text { masyarakat ini. }\end{array}$ \\
\hline Meningkatnya keterampilan & Keterampilan peserta akan di observasi saat \\
peserta setelah mendapat & pelatihan melalui pelatihan pembuatan aplikasi \\
pelatihan & sederhana emnggunakan Microsoft Access.
\end{tabular}

Sumber: diolah, 2021 


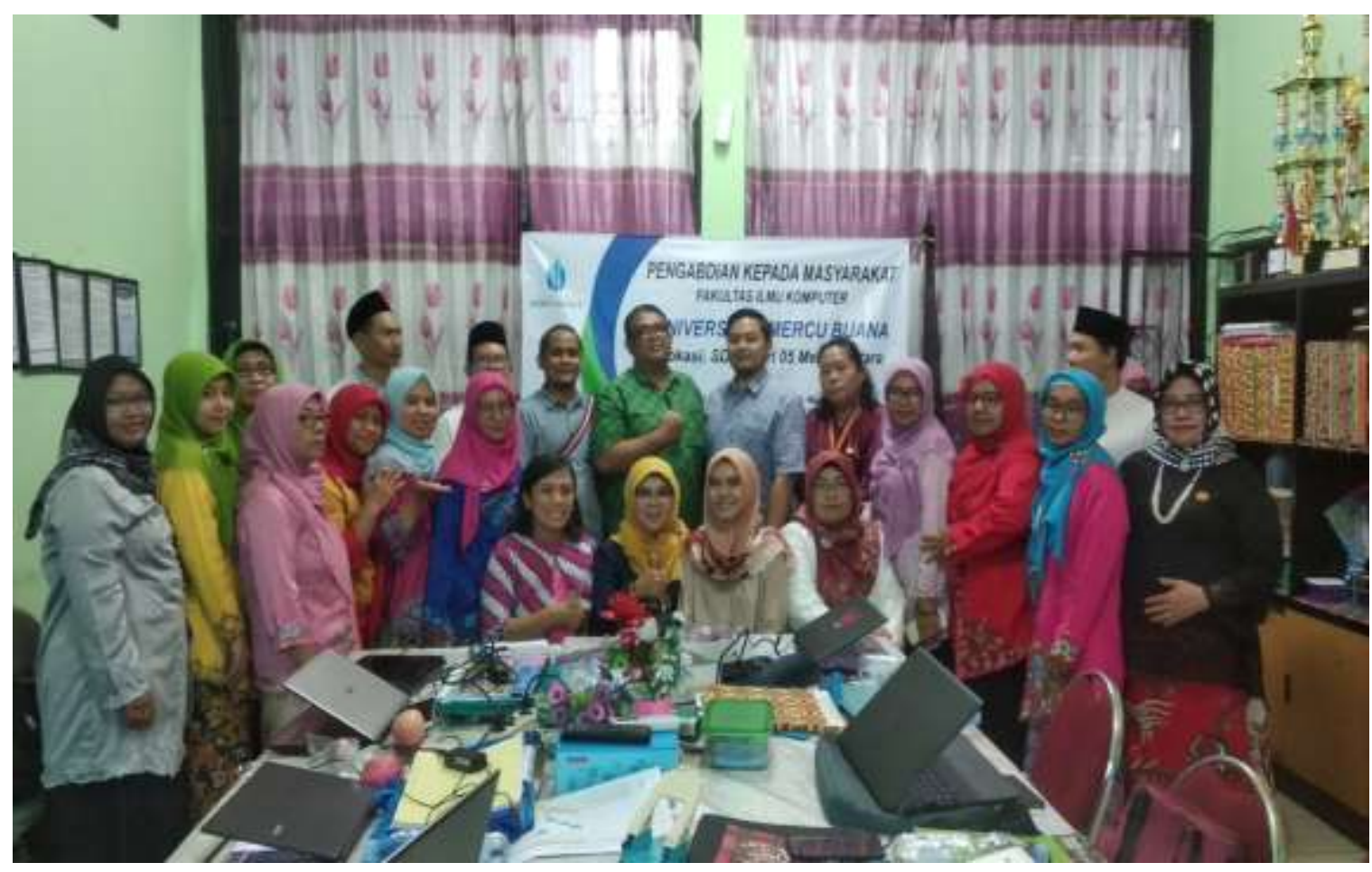

Gambar 5. Tim PKM Dengan Para Peserta Pelatihan

\section{Kesimpulan}

Dari hasil evaluasi serta temuan-temuan yang kami peroleh selama pelaksanaan kegiatan pengabdian masyarakat ini, dapat kami simpulkan bahwa program pengabdian masyartakat sebagai salah satu wujud dari pelaksanaan tri dharma perguruan tinggi ini telah mampu memberikan manfaat bagi Guru dan Staf Tata Usaha Sekolah Dasar 05 Meruya Utara yang menjadi sasaran pengabdian ini. Bentuk pelatihan seperti ini merupakan bentuk yang efektif untuk memberikan penyegaran dan wawasan baru di bidang teknologi informasi di luar proses pembelajaran yang diterima di luar pelatihan ini, dan dalam pelaksanaan Program Tri Dharma Perguruan Tinggi ini, yaitu pelatihan Kegiatan Pembuatan Aplikasi Pengisian dan Laporan Nilai Ujian Menggunakan Microsoft Access pada Wilayah Meruya Utara tidak ada kendala yang menghambat selama proses pelatihan. Sesuai dengan hasil evaluasi respons yang telah dilakukan, kami menyarankan hendaknya programprogram pegabdian masyarakat seperti ini dilaksanakan secara reguler dan berkala, melihat tingkat kebutuhan yang tinggi akan pengenalan aplikasi-aplikasi komputer yang baru dalam jangka waktu yang relatif singkat mengikuti perkembangan teknologi secara global. 


\section{Pengakuan/Acknowledgements}

Kami ucapkan terima kasih kepada ibu kepala sekolah SD Negeri 05 Meruya Utara atas kerjasamanya dan dukungannya atas kegiatan pelatihan ini. Kami juga mengucapkan terima kasih kepada Kepala Pusat Pengabdian Kepada Masyarakat Universitas Mercu Buana yang mendukung pelaksanaan kegiatan pengabdian ini.

\section{Daftar Referensi}

Kurniati. Sinring, A., \& Yasser, A. (2018). Pengembangan Sistem Informasi Layanan Bimbingan Konseling Berbasis Microsoft Acces Tingkat SMP Di Kabupaten Takalar.

Madcoms. (2014). Microsoft Access 2013 Untuk Pemula. Yogyakarta: CV Andi Offset.

Suwartika kusumadiarti, R., \& Taufik Muttaqin, R. (2019). Rancang Bangun Sistem Informasi Penjualan Di Toyota Auto 2000 PT. Astra Internasional Tbk Bandung.

Wagino. Ratna, S. Rahman, F. (2019). Sistem Informasi Akademik Pada SMPN 2 Gambut Berbasis Desktop. 